\title{
Improvement effect of cooked soybeans on HFD-deteriorated large intestinal health in rat model
}

\author{
Jae Ho Choi ${ }^{1}$ Taekyun $\mathrm{Shin}^{3} \cdot$ Myeong Seon Ryu ${ }^{4} \cdot$ Hee-Jong Yang ${ }^{4}$. \\ Do-Youn Jeong ${ }^{4}$ Tatsuya Unno ${ }^{1,2}$
}

\section{쥐 모델에서 고지방사료로 악화된 대장 건강에 대한 콩의 개선 효과}

\author{
최재호 ${ }^{1} \cdot$ 신태 균 $^{3}$ - 류명선 ${ }^{4} \cdot$ 양희종 ${ }^{4}$ - 정도연 ${ }^{4} \cdot$ 운노타쯔야 $^{1,2}$
}

Received: 3 September 2021 / Accepted: 15 October 2021 / Published Online: 31 December 2021

(C) The Korean Society for Applied Biological Chemistry 2021

\begin{abstract}
Obesity is associated with impaired intestinal epithelial barrier function, which contribute to host systemic inflammation and metabolic dysfunction. Korean traditional foods, fiber-rich bean products, have been various biological activities in antiinflammatory responses, but has not reported the large intestinal health. In this study, we investigated the intestinal health promoting effect of cooked soybeans (CSB) on high fat diet (HFD)-induced obesity model. SD rat were fed either a HFD or HFD supplemented with $10.6 \%$ CSB (HFD+CSB) for animal experimental period. CSB treatment significantly decreased the HFD-induced weights of body and fat. Also, CSB treatment improved HFD-reduced tight junction components (ZO-1, Claudin-1, and Occludin-1) mRNA expression in large intestine
\end{abstract}

Tatsuya Unno $(\triangle)$

E-mail: tatsu@jejunu.ac.kr

${ }^{1}$ Subtropical/Tropical Organism Gene Bank, SARI, Jeju National University, Jeju 63243, Republic of Korea

${ }^{2}$ Faculty of Biotechnology, College of Applied Life Sciences, SARI, Jeju National University, Jeju 63243, Republic of Korea

${ }^{3}$ Department of Veterinary Anatomy, College of Veterinary Medicine and Veterinary Medical Research Institute, Jeju National University, Jeju 63243, Republic of Korea

${ }^{4}$ Department of Research and Development, Microbial Institute for Fermentation Industry (MIFI), Sunchang 56048, Republic of Korea

This is an Open Access article distributed under the terms of the Creative Commons Attribution Non-Commercial License (http://creativecommons. org/licenses/by-nc/3.0/) which permits unrestricted non-commercial use, distribution, and reproduction in any medium, provided the original work is properly cited. tissue. Additionally, histopathological evaluation showed that CSB treatment attenuated the HFD-increased inflammatory cells infiltration and epithelial damages in large intestine tissue. At the genus level, effects of CSB supplement not yet clear, while dietary effects showed differential abundance of several genera including Lactobacillus, Duncaniella, and Alloprevotella. NMDS analysis showed significant microbial shifts by HFD, while CSB did not shift gut microbiota. CSB increased the abundance of the genera Anaerotignum, Enterococcus, Clostridium sensu stricto, and Escherichia/Shigella by linear discriminant analysis effect size analysis, while reduced the abundance of Longicatena and Ligilactobacillus. These findings indicate that CSB supplement improves HFD-deteriorated large intestinal health by the amelioration of tight junction component, while CSB did not shift gut microbiotas.

Keywords Cooked soybeans - Gut microbiota - High fat diet · Large intestinal health $\cdot$ Tight junction components

서 론

콩(Soybean)은 단백질, 지질, 탄수화물, 비타민 및 기타 무기질 로 구성된 식물로서, 단백질, 올리고당, 식이섬유, 이소플라본, 사 포닌, 레시틴, 피틴산, 단백질 분해효소 억제제, 피니톨 등 다양 한 생리활성물질을 함유하고 있어 심혈관계 질환, 소화기계 질 환, 당뇨병, 고혈압, 체중조절, 항암, 항염증 등 다양한 질환에 효능이 알려져 있다[1].

식품 원료로서 콩은 펙틴(Pectin)과 검류(Gum) 등 수용성 식 
이섬유는 장내미생물의 주요 에너지원인 아세트산(Acetic acid), 프로피오닉산(Propionic acid), 부틸릭산(Butyric acid) 등 단쇄지 방산의 생성하고 장내 유익균의 생육을 촉진하며, 셀룰로오스 (Cellulose)와 리그닌(Lignin) 등 불용성 식이섬유는 소화와 흡수 를 촉진하고 장의 연동운동을 증진하여 변비를 개선한다[2-5]. 또한, 콩에 함유된 이소플라본은 여성 호르몬인 에스트로겐과 구조적으로 유사하고, 생물학적 작용이 유사하기 때문에 조골세 포(Osteoblast)의 증식을 촉진하고 파골세포(Osteoclast)의 활성을 저해하여 여성의 폐경과 노화로 인한 골다공증의 예방 및 개선 에 유용하다는 연구 결과가 있다[6-8]. 이소플라본은 3phenylchrome 골격을 갖고 있는 화합물로서 genistein과 daidzein 은 항암과 더불어 각종 성인병의 예방과 치료 효능이 보고되어 있다[9].

식습관의 변화로 인한 장내 환경 변화는 장내미생물의 군집 변화를 유발하고, 염증성 장 질환의 발생 뿐만 아니라 최근에 는 자가면역질환, 비만, 당뇨 등 대사성질환은 새로운 사회문제 로 대두되었다. 특히, 동물모델에서 고지방식이는 체내 존재하 는 장내미생물의 불균형 유발, 변화 및 만성화로 인한 장 상피 장벽의 결합력을 감소시키고, 유해 장내 세균의 감염 증가로 인 한 장 누수 증후군(Leaky Gut)을 비롯한 장 질환의 유병률을 증가시키는 것으로 알려져 있다[10]. 비만으로 인한 장 질환 유 발과 관련된 임상적인 중요성에도 불구하고, 비만인 사람들의 장 건강측면에서 대장의 세포 결합력(Tight Junctions) 연구는 명확하지 않다. 콩의 다양한 효능으로 인해 식품, 화장품, 의약 품 등 다양한 기능성 소재로서 다양한 연구가 이루어져 왔으나, 장 건강측면에서 대장의 세포 결합력(Tight Junctions) 연구는 많지 않다[11]. 그럼으로, 본 연구에서는 고지방사료를 만성으로 섭취하여 비만 유도에 의한 장의 불균형을 유발하고, 장 건강 개선 효능을 지닌 기능성식품 소재로서 콩의 효능을 규명하고 자 한다.

\section{재료 및 방법}

\section{콩 제조}

실험에 사용된 대두는 전라북도 순창군에서 수확되는 백태를 사용 하였다. 대두는 24 시간 동안 물에 담가 충분히 불린 후 체에 걸러 수분을 제거하고 $121{ }^{\circ} \mathrm{C}$ 에서 30 분간 삶았다. 삶은 대두는 $40{ }^{\circ} \mathrm{C}$ 이 하로 식힌 후 발효미생물진흥원 $\left(35^{\circ} 22^{\prime} 02.5^{\prime \prime} \mathrm{N}, 127^{\circ} 06^{\prime} 20.9^{\prime \prime} \mathrm{E}\right)$ 의 항온항습기 조건 $\left(80 \%\right.$ 습도, $37^{\circ} \mathrm{C}$ 온도, 36 시간)에서 제조하였 다. 제조된 콩은 $60{ }^{\circ} \mathrm{C}$ 에서 24 시간 동안 건조하고 파쇄하여 동 물실험에 사용하였다.

\section{동물실험}

SPF 6주령 수컷 SD rat은 (주)대한바이오링크(Daejeon, Korea) 에서 구입하였다. 제주대학교 실험동물센터에 도착 후 (주)오리 엔트바이오의 설치류 식이(Gyeonggi-do, Korea)와 음용수는 자 유롭게 공급하고, 온도 $22 \pm 2{ }^{\circ} \mathrm{C}$, 상대습도 $50 \pm 5 \%$ 및 밤낮이 12 시간 간격의 조절되는 사육환경에서 1 주일 동안 적응시켰다. 고지방식이사료(HFD, DooYeol Biotech, Seoul, Korea)에서 구 매하였으며, 구성은 Table 1에 자세히 설명하였다. 제조된 콩 분 말은 식이의 약 $10.6 \%$ 를 차지하도록 배합하였다. Rat은 1 일 체 중 대비 약 $5 \%$ 의 사료를 섭취함으로, 콩이 함유된 고지방식이 는 1 일 $15-20 \mathrm{~g}$ 을 rat에 제공하였다. 고지방식이 내 콩의 함유 량은 $10.6 \%$ 이며, cage 내 식이는 rat이 모두 섭취하였다. 그럼 으로, rat이 1 일간 섭취한 콩의 양은 약 $1.6-2.2 \mathrm{~g}$ 입니다. 쥐를 무작위로 다음 3 개 그룹으로 나누었다( $\mathrm{N}=8$ 쥐/그룹): (1) 정상 식이 그룹(ND), (2) $\mathrm{HFD}$ 그룹(HFD) 및 (3) $\mathrm{HFD}+\mathrm{CSB}$ 그룹 (CSB). 실험 종료 후 대장은 적출하여 조직병리학적 분석을 위 해 $10 \%$ 포르말린 용액(DaeJung Chemicals \& Metals Co., Ltd., Siheung, Korea)에 고정하고, 나머지 대장 조직은 분석이 필요할 때까지 $-80{ }^{\circ} \mathrm{C}$ 초저온냉동고(Nihon, Tokyo, Japan)에 보

Table 1 The compositions and formulas of HFD

\begin{tabular}{|c|c|c|c|c|c|c|c|}
\hline \multirow{2}{*}{ Class description } & \multirow{2}{*}{ Ingredients } & \multicolumn{3}{|c|}{ HFD } & \multicolumn{3}{|c|}{ " HFD + CSB } \\
\hline & & $\mathrm{g} / \mathrm{Kg}$ & $\%$ & Kcal & $\mathrm{g} / \mathrm{Kg}$ & $\%$ & Kcal \\
\hline Protein & Casein & 265.0 & 28.4 & $1,060.0$ & 224.2 & 23.7 & 896.9 \\
\hline Protein & L-Cystine & 4.0 & 0.4 & 16.0 & 4.0 & 0.4 & 16.0 \\
\hline Carbohydrate & Maltodextrin & 160.0 & 17.1 & 640.0 & 142.8 & 15.1 & 571.2 \\
\hline Carbohydrate & Sucrose & 90.0 & 9.6 & 360.0 & 80.3 & 8.5 & 321.3 \\
\hline Fat & Lard & 310.0 & 33.2 & $2,790.0$ & 291.4 & 30.8 & $2,623.0$ \\
\hline Fat & Soybean Oil & 30.0 & 3.2 & 270.0 & 28.2 & 3.0 & 253.8 \\
\hline Fiber & Cellulose & 0.0 & 0.0 & 0.0 & 0.0 & 0.0 & 0.0 \\
\hline Mineral & Mineral Mix & 48.0 & 5.1 & 0.0 & 48.0 & 5.1 & 0.0 \\
\hline Vitamin & Vitamin Mix & 21.0 & 2.2 & 84.0 & 21.0 & 2.2 & 84.0 \\
\hline Vitamin & Choline Bitartrate & 3.0 & 0.3 & 0.0 & 3.0 & 0.3 & 0.0 \\
\hline Food additive & Calcium Phosphate & 3.4 & 0.4 & 0.0 & 3.4 & 0.4 & 0.0 \\
\hline Food additive & Cooked Soybeans & 0.0 & 0.0 & 0.0 & 100 & 10.6 & 453.8 \\
\hline Total & & 934.4 & 100.0 & $5,220.0$ & 946.4 & 100.0 & $5,220.0$ \\
\hline
\end{tabular}




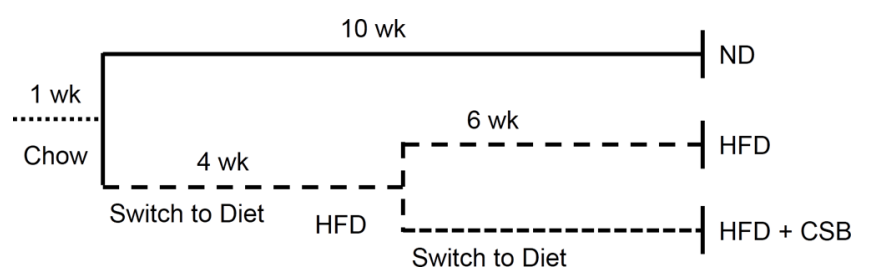

Fig. 1 Experimental design. SD rats fed the normal chow diet (ND) were changed to a high fat diet (HFD) for 4 weeks for acclimatization. After acclimatization to the HFD, 8 rats were fed with previous HFD and 8 rats were fed with cooked soybeans (CSB) for 6 weeks. On the last day, the large intestine was removed for histopathological analysis and stored at $80{ }^{\circ} \mathrm{C}$ deepfreezer until needed for analysis

관하였다. 모든 실험 프로토콜은 제주대학교 동물실험윤리위원 회 규칙 및 규정(제주대학교 동물실험윤리위원회, 승인번호 2020-0027)에 따라 수행되었습니다. 동물실험 계획은 Fig. 1에 명기하였다.

\section{조직병리학적 염색}

$10 \%$ 포르말린 용액으로 고정된 대장 조직은 파라핀 블록을 제 작하고 hematoxylin과 eosin 용액으로 염색하였다(Histoire, Seoul, Korea). 각 슬라이드의 조직병리학적 관찰은 제주대학교 수의과대학에서 광학현미경(Leica Microsystems, Wetzlar, Germany)으로 관찰하였다.

\section{RNA 분리, CDNA 합성 및 qPCR 수행}

RNAiso Plus reagent (Takara Korea Biomedical Inc., Seoul, Korea)을 사용하여 대장 조직에서 총 RNA를 추출하였다. 총 RNA 농도는 분광광도계 DS-11 plus (DENOVIX Inc., Wilmington, DE, USA)를 사용하여 정량 하였다. cDNA 합성 은 BioFACT ${ }^{\mathrm{TM}}$ RT Kit (BioFACT Inc., Daejeon, Korea)를 사용하여 $1 \mu \mathrm{g}$ 의 RNA로부터 합성하였다. ZO-1, Claudin-1, Occludin-1 및 $\beta$-actin과 같은 표적 유전자는 $\mathrm{TB} \mathrm{Green}^{\mathrm{TM}}$ Premix Ex Taq ${ }^{\mathrm{TM}}$ (Takara Korea Biomedical Inc., Seoul)을 이용한 $\mathrm{qPCR}$ 을 수행하였다. PCR 반응은 Thermal Cycler Dice $^{\circledR}$ Real Time System Lite (Takara Bio Inc., Shiga, Japan)를 사용하여 수행되었다. 연구에 사용된 PCR primer는 Macrogen, Inc (Seoul, Korea)에서 합성했으며, primer sequences 는 Table 2에 표기하였다.

\section{Gut microbiome analysis}

장내미생물생태 분석은 개별적으로 채취한 $\mathrm{SD}$ rat 분변 $200 \mathrm{mg}$ 으로부터 QIAamp PowerFecal Pro DNA Kit (QIAGEN, Germantown, $\mathrm{MD}, \mathrm{USA}$ )을 이용하여 추출한 $\mathrm{DNA}$ 를 사용하여 수행하였다. 모든 DNA 농도는 $5 \mathrm{ng} / \mu \mathrm{L}$ 으로 맞춰서 사용하였고, $16 \mathrm{~S}$ rRNA 유전자 내 V3-4 region을 대상으로 primer set을 사용한 two-step PCR 방법으로 증폭을 시행하였다[12]. Illumina MiSeq (Illumina, San Diego, CA, USA) 라이브러리 제작은 제조사에서 제공하고 있는 프로토콜에 따라 수행하였으 며, 최종적으로 제작한 $\mathrm{MiSeq}$ 라이브러리는 마크로젠(Seoul, Korea)으로 보내 시퀀싱을 수행하였다.

$16 \mathrm{~S}$ rRNA 유전자의 시퀀싱 데이터는 Mothur을 이용하여 분 석하였다[13]. 간략히 설명하면 'make.contigs' Mothur 서브루틴 을 이용하여 paired-end 형태의 염기서열을 합치는 과정을 수행 하였고, 'align.seqs' 서브루틴을 이용하여 SILVA database version 138 를 기반으로 alignment를 수행하였다[14]. 시퀀싱 과 정 중 발생하는 기계적인 오류로 생성된 염기서열을 수정하기 위해서 'pre.cluster' 서브루틴을 사용하였고, 'chimera.vsearch' 서브루틴은 chimeric sequences를 검출하기 위해서 수행하였다. Taxonomic classification은 RDP database를 이용하여 수행하였 고[15], $\alpha$-diversity 지표인 species richness (Chao I)와 species evenness (Shannon)을 계산하기 위해 'summary.single' 서브루틴 을 사용하였고, $\beta$-diversity는 'dist.shared' 서브루틴을 사용하여 Bray-Curtis distance를 기반으로 비교하여 non-metric multidimensional scaling (NMDS)로 나타냈다.

\section{통계처리}

모든 통계 분석은 GraphPad Software (San Diego, CA, USA) 을 사용하여 수행하였다. 통계적 유의성 평가는 일원 분산 분 석 (ANOVA)에 의한 Tukey-Kramer test를 사용하여 결정되었 으며, 통계학적 유의 수준은 $p<0.01$ 와 $p<0.001$ 이었다. $\alpha$-diversity 지표는 분산 분석(analysis of variance, ANOVA)을 사용하여 비교 분석하였고, 미생물생태 간 차이는 분자 분산 분석 (analysis of molecular variance, AMOVA)을 사용하여 측정하 였다. 그룹 간 미생물의 abundance 차이는 linear discriminant analysis effect size (LEfSe)를 계산하였으며, LEfSe $>3$ 이고, $\mathrm{p}$ value $<0.05$ 을 기준으로 유의적으로 차이를 나타내는 미생물을 조사하였다[16]. Heatmap은 R software에서 pheatmap package 를 사용하여 나타냈다.

Table 2 Primer sequences for qPCR

\begin{tabular}{|c|c|c|c|}
\hline Gene & & Sequences & NCBI Number \\
\hline \multirow{2}{*}{$\mathrm{ZO}-1$} & $\mathrm{~F}$ & CTGCCTCGAACCTCTACTC & \multirow{2}{*}{ NM_001106266.1 } \\
\hline & $\mathrm{R}$ & TAACTTCGTGGGTACTGGTCAA & \\
\hline \multirow{2}{*}{ Claudin-1 } & $\mathrm{F}$ & TGCAGCTTCTGGGTTTCA & \multirow{2}{*}{ NM_031699.3 } \\
\hline & $\mathrm{R}$ & AAACGCAGGACATCCACA & \\
\hline \multirow{2}{*}{ Occludin-1 } & $\mathrm{F}$ & ATCCTGTCTATGCTCGTCA & \multirow{2}{*}{ NM_031329.3 } \\
\hline & $\mathrm{R}$ & GTAACCTCCGAAGCCACC & \\
\hline \multirow{2}{*}{$\beta$-actin } & $\mathrm{F}$ & TGGCACCACCATGTACC & \multirow{2}{*}{ NM_031144.3 } \\
\hline & $\mathrm{R}$ & CCACCAATCCACACAGAGT & \\
\hline
\end{tabular}


Table 3 Effects of CSB on the HFD-induced body weight gain in rat

\begin{tabular}{ccccc}
\hline \hline Group & Initial Body Weight $(\mathrm{g})$ & Final Body Weight $(\mathrm{g})$ & Body Weight Change $(\mathrm{g})$ & Fat Weight $(\mathrm{g})$ \\
\hline ND & $205.2 \pm 5.1$ & $261.6 \pm 7.6$ & $56.4 \pm 8.9$ & $5.1 \pm 0.4$ \\
HFD & $204.9 \pm 3.9$ & $424.9 \pm 4.7^{\text {\#\# }}$ & $220.0 \pm 4.0^{\text {\#\#\# }}$ & $27.9 \pm 1.6^{\text {\#\# }}$ \\
HFD + CSB & $201.4 \pm 6.8$ & $375.1 \pm 9.8^{* * *}$ & $173.8 \pm 8.2^{* * *}$ & $19.8 \pm 1.8^{* * *}$ \\
\hline
\end{tabular}

Results were indicated as mean \pm standard deviation $(\mathrm{N}=8)$. Compared with $\mathrm{ND},{ }^{\#} p<0.001$, compared with $\mathrm{HFD},{ }^{* * *} p<0.001$. ND, HFD, and CSB represented the normal diet group, the $60 \%$ HFD group, and the HFD + CSB group, respectively

\section{결과 및 고찰}

\section{체중 변화 및 지방 축적에 대한 $\mathrm{CSB}$ 의 개선 효과}

대두 및 그 변형 제품의 섭취는 비만유도모델에서 식이에 의해 증가된 체중과 지방 무게의 감소 효과는 과학적으로 입증되었 다[17-20]. 본 연구에서는 고지방식이에 유도된 비만 모델에서 삶은 콩 $(\mathrm{CSB})$ 에 대한 체중 변화 및 지방 축적에 대한 개선 효 과를 조사하였다. 6주령 수컷 $\mathrm{SD}$ 쥐를 새로운 환경에 일주일 동안 적응 후, 정상군은 일반 사료 $(\mathrm{ND})$ 를 제공하고, 실험군은 $60 \%$ 고지방 사료 $(\mathrm{HFD})$ 를 4주간 제공하였다. 그 후 실험군 중 일부는 콩이 혼합된 고지방 사료 $(\mathrm{HFD}+\mathrm{CSB})$ 로 전환하고 6 주 간 제공하였다. 일반 사료에 비해 고지방 사료를 10 주간 섭취 하면 체중 증가는 지방 축적을 통해 유의하게 증가되었다. 그 러나 $10.6 \%$ 콩이 혼합된 고지방 사료 $(\mathrm{HFD}+\mathrm{CSB})$ 의 섭취는 고 지방 사료(HFD)만을 섭취한 쥐에 비해 체중 증가와 지방 축적
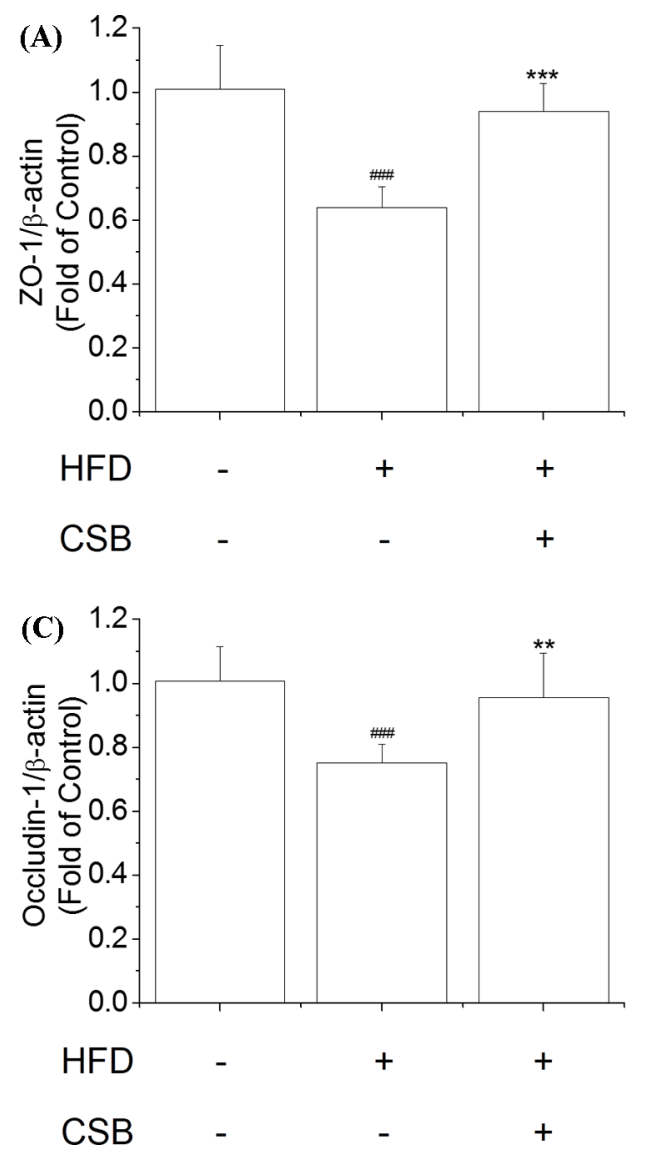

이 현저히 감소됨을 확인하였다(Table 3).

콩은 단백질, 이소플라본, 식이섬유가 풍부한 식물로서 항비 만 효과와 더불어 지방축적 감소와 연관성이 있는 것으로 알려 져 있다[21,22]. 최근 $\mathrm{CSB}$ 의 이소플라본을 측정한 결과, Genistin $(153 \pm 8.9 \mathrm{mg} / \mathrm{g})$, Daidzin $(93.3 \pm 6.4 \mathrm{mg} / \mathrm{g})$ 및 Glycitin $(23.2 \pm 1.8 \mathrm{mg} / \mathrm{g})$ 등으로 높게 측정되었다.[23]. 이러한 기존 연구 들은 콩 제품의 섭취는 식이에 의해 유발된 비만모델에서 체중 증가와 지방 축적을 개선한다는 본 연구의 결과와 동일한 것이 다. 따라서, 콩 $(\mathrm{CSB})$ 의 섭취는 고지방식이에 의해 증가된 체 중 변화와 지방 축적 개선에 효과적임을 확인할 수 있다.

\section{대장 상피 장벽 파괴에 대한 $\mathrm{CSB}$ 의 개선 효과}

장은 필수 영양소를 흡수할 뿐만 아니라 다양한 섭취 독소와 장내 미생물로부터 숙주를 보호한다. 대장 상피 장벽은 점액층, 장 상피 세포 및 밀착 연접 단백질로 구성되어 있으며, 섭취하

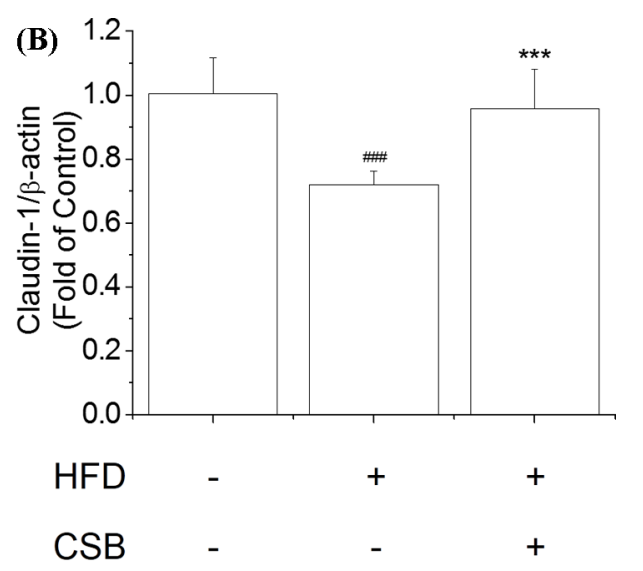

Fig. 2 Inhibitory effect of cooked soybeans (CSB) on HFD-induced disruption of the large intestine epithelial barrier in rats. The mRNA expression of ZO-1 (A), Claudin-1 (B), and Occludin-1 (C) was determined by $\mathrm{qPCR}$ analysis. Results are indicated as means $\pm \mathrm{SD}(\mathrm{n}=8)$.

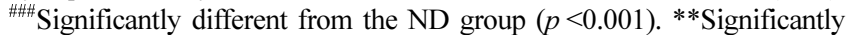
different from the HFD-fed group $(p<0.01)$. ${ }^{* * *}$ Significantly different from the HFD-fed group $(p<0.001)$ 

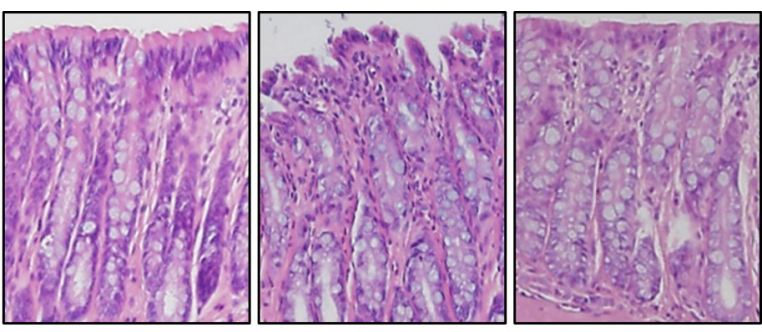

HFD

CSB

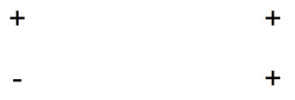

Fig. 3 Inhibitory effect of cooked soybeans (CSB) on HFD-induced histopathological changes in large intestine. Large intestine tissue was stained by $H \& E$ stain and representative H\&E-stained large intestine tissues were photographed at $100 \times$ magnification under the microscope for histopathological analysis

는 식이 종류에 대장 장벽이 쉽게 붕괴된다. 대장 장벽 구성 요 소가 붕괴되면, 장내 내용물에 대한 장 투과성이 증가하여 염 증성 장 질환, 괴사성 장염, 셀리악병과 같은 장 질환을 유발한 다고 알려져 있다[24]. 여러 연구에 따르면 과도한 지방 섭취는 장 상피 장벽을 파괴하고 긴밀한 접합부의 견고성을 감소시켜 장내 세균에 의한 장 누수를 증가시킨다고 알려져 있다[11,25]. 본 연구에서는 비만과 관련된 장 상피 장벽의 결합 정도를 기 능적으로 평가하기 위해 대장 조직에서 밀착 결합 지표(Tight Junctions marker)에 대한 mRNA 발현을 조사하였다. ZO-1, Claudin-1 및 Occludin-1을 포함하는 상피 장벽 완전성을 조절 하는 밀착 결합 지표의 $\mathrm{mRNA}$ 발현은 만성 고지방 사료 (HFD) 섭취에 의해 감소하였다. 그러나, 콩이 혼합된 고지방 사 료 $(\mathrm{HFD}+\mathrm{CSB})$ 를 섭취하면 고지방 사료(HFD)에 의해 감소된 밀착 결합 지표의 mRNA 발현이 회복되었다(Fig. 2).

최근, 12 주간 고지방 사료를 섭취한 $\mathrm{C} 57 \mathrm{BL} / 6$ 마우스에서 대 장의 장내 장벽 기능 강화와 관련된 밀착 결합 지표(ZO-1, Claudin-1 및 Occludin-1)들이 감소되었으나, $15.7 \%$ navy beans 이 혼합된 고지방 사료를 섭취한 그룹은 밀착 결합 지표의 mRNA 발현이 고지방 사료(HFD)로부터 보호되는 것을 확인하 였다[11]. 이러한 보고는 콩 제품의 섭취가 식이에 의한 대장의 장내 장벽 기능을 강화시킨다는 본 연구의 결과와 동일한 것이 다. 따라서, 콩 $(\mathrm{CSB})$ 의 섭취는 고지방식이에 의해 대장 상피 장 벽 개선에 효과적임을 확인할 수 있다.

\section{조직병리학적 변화에 대한 CSB의 개선 효과}

다음으로, 고지방 사료를 섭취한 대장 상피 조직의 붕괴 정도 를 평가하기 위해 조직병리학적 분석을 수행하였다. 본 실험에 서 고지방 사료(HFD)를 만성으로 섭취한 모델의 대장 상피 조 직에서 염증 세포의 침윤과 상피 조직의 손상이 나타나는 것을 확인하였다. 고지방 사료(HFD)만을 섭취한 모델에서 심각한 염 증 세포의 침윤과 상피 조직의 붕괴가 나타났으나, 콩이 혼합 된 고지방 사료 $(\mathrm{HFD}+\mathrm{CSB})$ 를 섭취함으로써 개선되었다(Fig. 3). 우리의 결과는 콩 제품의 섭취가 대장 상피 장벽의 완전성 과 염증 세포의 침윤을 개선한다는 이전의 연구들과 동일하다 [26-28]. 본 연구를 기반으로 장 건강을 위해 1 일 기준 33.8-

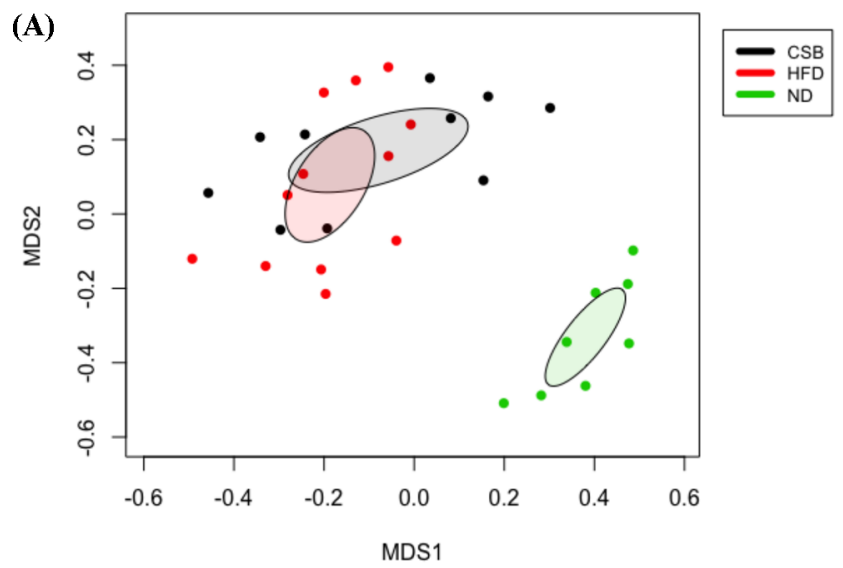

(B)

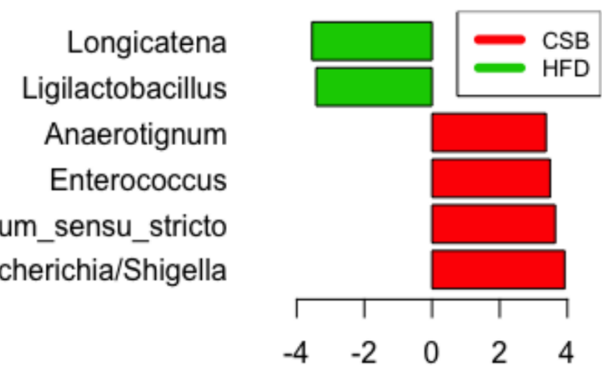

Fig. 4 Beta-diversity analysis. Beta-diversity analysis using non-metric multidimensional scaling (NMDS) analysis (A) and differential abundance analysis at the genus level between HFD and ND groups (B) and HFD and CSB groups (C)

$46.5 \mathrm{~g}$ 의 콩을 섭취할 것을 권장한다. 따라서, 우리는 콩 $(\mathrm{CSB})$ 의 섭취는 대장 건강에 유익한 효과를 나타낼 수 있음을 시사한다.

\section{장내미생물의 변화에 대한 $\mathrm{CSB}$ 의 영향}

본 연구에서 사용한 시퀀스 데이터는 Erroneous sequence removal 과정을 거쳐 총 $1,586,264$ reads를 얻었으며, 모든 샘 플에서 최저 reads수는 31,429 reads로 확인되었다. Figure S1 은 HFD 섭취가 species richness를 감소시키고 evenness에는 영향을 미치지 않았지만, $\mathrm{CSB}$ 는 $\alpha$-diversity에 영향이 없었다는 것을 나타낸다. Figure S2는 식이 변화(ND vs HFD)나 첨가 변화 (HFD vs CSB) 모두 phylum 수준에서 미생물생태에 대 한 명확한 차이를 보이지 않았지만, $\mathrm{ND}$ 와 $\mathrm{HFD}$ 간 차이는 family 수준에서 유의적인 차이가 확인되었다. 또한, HFD 섭취 는 대부분 Lactobacillaceae에 속하는 미생물이 감소하는 반면 family 수준에서 Bacteroidaceae와 Lachnospiraceae가 증가하는 것으로 관찰되었다. 그러나, $\mathrm{CSB}$ 첨가는 heatmap으로 나타낸 genus 수준의 장내미생물생태에서 차이가 없었으나 고지방식이 섭취 여부에 따라 Lactobacillus, Duncaniella, Alloprevotella 등 을 포함한 미생물 종에 대해 abundance 차이가 확인되었다. $\mathrm{NMDS}$ 분석은 고지방식이 섭취에 의해 장내미생물생태가 유의 적으로 변화하지만 $(p<0.01) \mathrm{CSB}$ 첨가는 차이가 없었다는 것을 나타낸다(Fig. $4 \mathrm{~A})$. LEfSe는 $\mathrm{HFD}$ 와 $\mathrm{CSB}$ 간 유의적으로 차이 가 나타나는 genera를 조사하기 위해 수행하였는데, CSB 첨가 는 Anaerotignum, Enterococcus, Clostridium sensu stricto, 
Escherichia/Shigella의 abundance가 증가시켰으나 Longicatena와 Ligilactobacillus를 감소시켰다(Fig. 4B). Longicatena는 family Erysipelotrichaceae에 속하는 미생물 종으로 장 염증과 밀접한 관련이 있다고 알려져 있다[29]. Ligilactobacillus는 lactic acid 를 생산하는 미생물 중 하나로 probiotics로 알려져 있다[30]. 또 한, Anaerotignum는 short-chain fatty acid (SCFA) 생성균으로 알려져 있으나[30], Escherichia coli의 증가는 건강하지 못한 장 내 환경을 갖고 있다는 것을 나타낸다[31]. 장내미생물 기반 대 사 활성도를 조사하기 위해 수행한 PICRUSt 분석에서도 HFD 와 $\mathrm{CSB}$ 간 차이를 확인할 수 없어(Data not shown), 고지방식 이 섭취 시 $\mathrm{CSB}$ 첨가가 장내 미생물 생태에 긍정적인 효과를 미치는지에 대해서는 명확하지 않았다.

결론적으로, 장내미생물은 SCFA 생성을 증가시키고 tight junctions의 견고성 강화와 관련되어 있으며, 실험동물에서 프로 바이오틱스의 투여가 tight junctions의 결합력을 강화시킨다고 알려져 있다[24]. 그러나, 본 연구에서 고지방식이에 비해 CSB 를 투여한 그룹에서 두드러진 장내미생물의 변화를 확인할 수 없어, 고지방식이에 의해 악화된 장 세포의 결합력 개선과 관 련된 장내미생물의 긍정적인 영향은 명확히 설명할 수 없다.

\section{초 록}

비만은 숙주의 전신 염증 및 대사 기능 장애에 기여하는 장 상 피 장벽 기능 저하와 관련이 있다. 한국의 전통 식품으로 식이 섬유가 풍부한 콩 제품은 항염증 반응을 비롯한 다양한 생물학 적 활성을 나타내어 왔으나 대장 건강에 대해서는 보고된 바가 없다. 본 연구에서는 고지방 식이(HFD)를 섭취한 비만 모델에 서 콩 $(\mathrm{CSB})$ 에 대한 장 건강 증진 효과를 조사하였다. $\mathrm{SD}$ 쥐에 게 동물 실험 기간 동안 $\mathrm{HFD}$ 또는 $10.6 \% \mathrm{CSB}$ 가 함유된 $\mathrm{HFD}(\mathrm{HFD}+\mathrm{CSB})$ 를 제공하였다. $\mathrm{CSB}$ 의 섭취는 $\mathrm{HFD}$ 로 유발 된 체중과 지방 축적 증가를 현저하게 감소시켰다. 또한, $\mathrm{CSB}$ 의 섭취는 대장 조직에서 $\mathrm{HFD}$ 에 의해 감소된 밀착 결합 지표 (ZO-1, Claudin-1 및 Occludin-1)의 mRNA 발현을 개선시켰다. 또한, 조직병리학적 평가에서도 $\mathrm{CSB}$ 섭취는 대장 조직에서 $\mathrm{HFD}$ 에 의해 증가된 염증 세포 침윤과 대장 상피 조직 붕괴를 개선하는 것으로 나타났다.

Genus 수준에서 HFD 섭취에 의해 Lactobacillus, Duncaniella, Alloprevotella 등 미생물 종의 abundance 차이는 확인되었으나, $\mathrm{CSB}$ 섭취로 인한 영향은 명확하게 나타나지 않았다. NMDS 분 석에서 $\mathrm{HFD}$ 섭취에 의해 유의적인 장내미생물 생태 이동을 보 여주었지만 $\mathrm{CSB}$ 섭취는 차이가 없었다. $\mathrm{HFD}$ 와 $\mathrm{CSB}$ 간 유의 적으로 차이가 나타나는 genera를 조사하기 위해 LEfSe를 수행 한 결과, $\mathrm{CSB}$ 는 Anaerotignum, Enterococcus, Clostridium sensu stricto 및 Escherichia/Shigella 속의 풍부함을 증가시킨 반면 Longicatena 및 Ligilactobacillus의 풍부함을 감소시켰다.

이러한 결과는 $\mathrm{CSB}$ 섭취는 긴밀한 접합 성분을 개선하여 $\mathrm{HFD}$ 로 악화된 대장 건강을 개선하는 반면 장내미생물생태에 긍정적인 효과를 미치는지에 대해서는 명확하지 않았다.

Keywords 고지방 식이 - 밀착 결합 성분 - 장 건강 증진 효 과 · 장내미생물 · 콩
감사의 글 이 연구는 교육부 및 과학기술정보통신부의 재원으로 한국연구 재단(NRF)의 지원을 받아 수행된 기초과학연구 프로그램(2016R1A6A1A 03012862) 및 전통문화융합연구사업(NRF-2016M3C1B5907152) 입니다. 실 험 시설 및 실험 장비를 제공해주신 제주대학교 친환경농업연구소(SARI)에 감사드립니다.

\section{References}

1. Kim IS, Kim CH, Yang WS (2021) Physiologically Active Molecules and Functional Properties of Soybeans in Human Health-A Current Perspective. Int J Mol Sci 22: 4054. doi: 10.3390/ijms22084054

2. Ashaolu TJ, Ashaolu JO, Adeyeye SAO (2021) Fermentation of prebiotics by human colonic microbiota in vitro and short-chain fatty acids production: a critical review. J Appl Microbiol 130: 677-687. doi: 10.1111/jam.14843

3. Markowiak-Kopec P, Slizewska K (2020) The Effect of Probiotics on the Production of Short-Chain Fatty Acids by Human Intestinal Microbiome. Nutrients 12: 1107. doi: 10.3390/nu12041107

4. Lattimer JM, Haub MD (2010) Effects of dietary fiber and its components on metabolic health. Nutrients 2: 1266-1289. doi: 10.3390/ nu2121266

5. Muller M, Canfora EE, Blaak EE (2018) Gastrointestinal Transit Time, Glucose Homeostasis and Metabolic Health: Modulation by Dietary Fibers. Nutrients 10: 275. doi: 10.3390/nu10030275

6. Chen LR, Ko NY, Chen KH (2019) Isoflavone Supplements for Menopausal Women: A Systematic Review. Nutrients 11: 2649. doi: 10.3390/nu11112649

7. Abdel-Daim MM, El-Tawil OS, Bungau SG, Atanasov AG (2019) Applications of Antioxidants in Metabolic Disorders and Degenerative Diseases: Mechanistic Approach. Oxid Med Cell Longev 2019: 4179676. doi: $10.1155 / 2019 / 4179676$

8. Lanou AJ (2011) Soy foods: are they useful for optimal bone health? Ther Adv Musculoskelet Dis 3: 293-300. doi: 10.1177/1759720X11417749

9. Panche AN, Diwan AD, Chandra SR (2016) Flavonoids: an overview. J Nutr Sci 5: e47. doi:10.1017/jns.2016.41

10. Ahmad R, Rah B, Bastola D, Dhawan P, Singh AB (2017) Obesityinduces Organ and Tissue Specific Tight Junction Restructuring and Barrier Deregulation by Claudin Switching. Sci Rep 7: 5125. doi: 10.1038/s41598-017-04989-8

11. Monk JM, Wu W, Lepp D, Wellings HR, Hutchinson AL, Liddle DM, Graf D, Pauls KP, Robinson LE, Power KA (2019) Navy bean supplemented high-fat diet improves intestinal health, epithelial barrier integrity and critical aspects of the obese inflammatory phenotype. J Nutr Biochem 70: 91-104. doi: 10.1016/j.jnutbio.2019.04.009

12. Singh V, Muthuramalingam K, Kim YM, Park S, Kim SH, Lee J, Hyun C, Unno T, Cho M (2021) Synbiotic supplementation with prebiotic Schizophyllum commune derived $\beta$ - $(1,3 / 1,6)$-glucan and probiotic concoction benefits gut microbiota and its associated metabolic activities. Appl Biol Chem 64: 1-10. doi: 10.1186/s13765-020-00572-4

13. Schloss PD, Westcott SL, Ryabin T, Hall JR, Hartmann M, Hollister EB, Lesniewski RA, Oakley BB, Parks DH, Robinson CJ, Sahl JW, Stres B, Thallinger GG, Van Horn DJ, Weber CF (2009) Introducing mothur: open-source, platform-independent, community-supported software for describing and comparing microbial communities. Appl Environ Microbiol 75: 7537-7541. doi: 10.1128/AEM.01541-09

14. Quast C, Pruesse E, Yilmaz P, Gerken J, Schweer T, Yarza P, Peplies J, Glockner FO (2013) The SILVA ribosomal RNA gene database project: improved data processing and web-based tools. Nucleic Acids Res 41: D590-596. doi: 10.1093/nar/gks1219

15. Wang Q, Garrity GM, Tiedje JM, Cole JR (2007) Naive Bayesian classifier for rapid assignment of rRNA sequences into the new bacterial taxonomy. Appl Environ Microbiol 73: 5261-5267. doi: 10.1128/ AEM.00062-07 
16. Segata N, Izard J, Waldron L, Gevers D, Miropolsky L, Garrett WS, Huttenhower C (2011) Metagenomic biomarker discovery and explanation. Genome Biol 12: R60. doi: 10.1186/gb-2011-12-6-r60

17. Lee JY, Aravinthan A, Park YS, Hwang KY, Seong SI, Hwang K (2016) Supplementation of a Fermented Soybean Extract Reduces Body Mass and Prevents Obesity in High Fat Diet-Induced C57BL/6J Obese Mice. Prev Nutr Food Sci 21: 187-196. doi: 10.3746/pnf.2016.21.3.187

18. Choi JH, Pichiah PB, Kim MJ, Cha YS (2016) Cheonggukjang, a soybean paste fermented with B. licheniformis- 67 prevents weight gain and improves glycemic control in high fat diet induced obese mice. J Clin Biochem Nutr 59: 31-38. doi: 10.3164/jcbn.15-30

19. Nam YR, Won SB, Chung YS, Kwak CS, Kwon YH (2015) Inhibitory effects of Doenjang, Korean traditional fermented soybean paste, on oxidative stress and inflammation in adipose tissue of mice fed a high-fat diet. Nutr Res Pract 9: 235-241. doi: 10.4162/nrp.2015.9.3.235

20. Oh HG, Kang YR, Lee HY, Kim JH, Shin EH, Lee BG, Park SH, Moon DI, Kim OJ, Lee IA, Choi J, Lee JE, Park KH, Suh JW (2014) Ameliorative effects of Monascus pilosus-fermented black soybean (Glycine max L. Merrill) on high-fat diet-induced obesity. J Med Food 17: 972-978. doi: 10.1089/jmf.2012.2740

21. Velasquez MT, Bhathena SJ (2007) Role of dietary soy protein in obesity. Int J Med Sci 4: 72-82. doi: 10.7150/ijms.4.72

22. Naaz A, Yellayi S, Zakroczymski MA, Bunick D, Doerge DR, Lubahn DB, Helferich WG, Cooke PS (2003) The soy isoflavone genistein decreases adipose deposition in mice. Endocrinology 144: 3315-3320. doi: 10.1210/en.2003-0076

23. Jeong DY, Daily JW, Lee GH, Ryu MS, Yang HJ, Jeong SY, Qiu JY, Zhang T, Park S (2020) Short-Term Fermented Soybeans with Bacillus amyloliquefaciens Potentiated Insulin Secretion Capacity and Improved Gut Microbiome Diversity and Intestinal Integrity To Alleviate Asian Type 2 Diabetic Symptoms. J Agric Food Chem 68: 13168-13178. doi: $10.1021 /$ acs.jafc. 9 b07962
24. Rohr MW, Narasimhulu CA, Rudeski-Rohr TA, Parthasarathy S (2020) Negative Effects of a High-Fat Diet on Intestinal Permeability: A Review. Adv Nutr 11: 77-91. doi: 10.1093/advances/nmz061

25. Rohr MW, Narasimhulu CA, Rudeski-Rohr TA, Parthasarathy S (2020) Negative Effects of a High-Fat Diet on Intestinal Permeability: A Review. Adv Nutr 11: 77-91. doi: 10.1093/advances/nmz061

26. Woo JK, Choi S, Kang JH, Kim DE, Hurh BS, Jeon JE, Kim SY, Oh SH (2016) Fermented barley and soybean (BS) mixture enhances intestinal barrier function in dextran sulfate sodium (DSS)-induced colitis mouse model. BMC Complement Altern Med 16: 498. doi: 10.1186/s12906016-1479-0

27. Catalan N, Villasante A, Wacyk J, Ramirez C, Romero J (2018) Fermented Soybean Meal Increases Lactic Acid Bacteria in Gut Microbiota of Atlantic Salmon (Salmo salar). Probiotics Antimicrob Proteins 10: 566-576. doi: 10.1007/s12602-017-9366-7

28. Kim JH, Won YS, Cho HD, Hong SM, Moon KD, Seo KI (2020) Protective Effect of Prunus mume Fermented with Mixed Lactic Acid Bacteria in Dextran Sodium Sulfate-Induced Colitis. Foods 10: 58. doi: $10.3390 /$ foods 10010058

29. Kaakoush NO (2015) Insights into the Role of Erysipelotrichaceae in the Human Host. Front Cell Infect Microbiol 5: 84. doi: 10.3389/fcimb. 2015.00084

30. Ueki A, Goto K, Ohtaki Y, Kaku N, Ueki K (2017) Description of Anaerotignum aminivorans gen. nov., sp. nov., a strictly anaerobic, amino-acid-decomposing bacterium isolated from a methanogenic reactor, and reclassification of Clostridium propionicum, Clostridium neopropionicum and Clostridium lactatifermentans as species of the genus Anaerotignum. Int J Syst Evol Microbiol 67: 4146-4153. doi:10.1099/ijsem.0.002268

31. Baldelli V, Scaldaferri F, Putignani L, Del Chierico F (2021) The Role of Enterobacteriaceae in Gut Microbiota Dysbiosis in Inflammatory Bowel Diseases. Microorganisms 9: 10.3390/microorganisms9040697 